\title{
Early parenteral nutrition in enterectomized $\operatorname{dog} \mathbf{s}^{1}$
}

\author{
Geni C.F. Patricio ${ }^{2 *}$, Ana R. Eyherabide ${ }^{2}$, Ricardo A. Dias², Uenis Tannuri ${ }^{3}$, \\ Marcio A. Brunetto ${ }^{2}$ and Silvia R.G. Cortopassi ${ }^{2}$
}

\begin{abstract}
Patricio G.C.F., Eyherabide A.R., Dias R.A., Tannuri U., Brunetto M.A. \& Cortopassi S.R.G. 2018. Early parenteral nutrition in enterectomized dogs. Pesquisa Veterinária Brasileira 38(3):482-488. Faculdade de Medicina Veterinária e Zootecnia, Universidade de São Paulo, Avenida Prof. Orlando Marques de Paiva 87, Cidade Universitária, São Paulo, SP 05508-270, Brazil. E-mail: silcorto@usp.br

The aim of this study was to explore the role of early central parenteral nutrition support with and without lipid emulsion in enterectomized dogs undergoing small bowel partial resection. Enterectomized dogs often cannot be fed properly via an oral or enteral route immediately post-surgery. After enterectomy, the animals received parenteral nutrition or crystalloid solution until they were able to voluntarily take in an oral diet. All dogs were recruited at the University of Sao Paulo veterinary teaching hospital. Eighteen dogs with intussusception, a foreign intestinal body, linear foreign intestinal body, or intussusception associated with a foreign intestinal body underwent enterectomy surgery and were randomly assigned to receive one of three treatments: crystalloid solution (CS group), parenteral nutrition with a mix of glucose and amino acids (GA group) or parenteral nutrition with a mix of glucose, amino acids and lipids (GAL group). A serum chemistry panel and complete blood count were collected prior to surgery and at the end of the study. Albumin increased in the GA and GAL group ( $\mathrm{p}=0.042$ and $\mathrm{p}=0.038$ respectively) after hospitalization, but no significant differences were identified among the groups. Body weight decreased by $4.9 \%(p=0.042)$ in the CS group, but there were no significant changes in the GAL and GA groups. There was a significant decrease in the recovery scores in the GA and GAL groups during hospitalization $(p=0.039$ in both groups). Early parenteral nutrition was beneficial for patient recovery in post-surgical small bowel partial resection, indicating better quality, and no major complications or side effects were observed during the hospitalization period in the studied dogs.

INDEX TERM: Early parenteral nutrition, enterectomized dogs, intensive therapy, dogs, surgery.
\end{abstract}

RESUMO.- [Nutrição parenteral precoce em cães submetidos à enterectomia.] 0 objetivo desse estudo era estudar os efeitos da nutrição parenteral central precoce com e sem emulsão lipídica em cães submetidos à ressecção parcial do intestino delgado. Os cães enterectomizados frequentemente não conseguem ser adequadamente alimentados por via oral ou enteral no pós-cirúrgico imediato. Após a enterectomia, os animais receberam nutrição parenteral ou solução cristaloide

\footnotetext{
${ }^{1}$ Received on September 20, 2016.

Accepted for publication on July 17, 2017.

${ }^{2}$ Faculdade de Medicina Veterinária e Zootecnia, Universidade de São Paulo (USP), Avenida Prof. Orlando Marques de Paiva 87, Cidade Universitária, São Paulo, SP 05508-270, Brazil. *Corresponding author: silcorto@usp.br

${ }^{3}$ Faculdade de Medicina, Universidade de São Paulo, Avenida Dr. Arnaldo 455, Cerqueira César, São Paulo, SP 01246-903, Brazil.
}

até o momento em que fossem capazes de alimentar-se voluntariamente por via oral. Todos os animais foram selecionados no hospital veterinário da Universidade de São Paulo. Dezoito cães diagnosticados com intussuscepção, corpo estranho intestinal, corpo estranho linear ou intussuscepção associada com corpo estranho intestinal foram submetidos à enterectomia e aleatoriamente alocados para receber um dos três tratamentos: solução cristaloide (grupo CS), nutrição parenteral com mistura de glicose e aminoácidos (grupo GA) ou nutrição parental com mistura de glicose e lipídios (grupo GAL). Hemograma e bioquímica sérica foram coletados antes da cirurgia e no final do estudo. Houve aumento de albumina no grupo GA e GAL ( $p=0,042$ e $p=0,038$ respectivamente) após a hospitalização, mas não houve diferença significativa entre grupos. 0 peso corpóreo diminuiu cerca de 4,9\% ( $\mathrm{p}=0,042)$ no grupo CS mas não 
houve alterações significativas no grupo GAL e GA. Houve uma diminuição significativa no escore de recuperação no grupo GA e GAL durante a hospitalização ( $p=0,039$ em ambos os grupos). A nutrição parenteral precoce mostrou-se benéfica para a recuperação no pós-operatório dos cães submetidos à ressecção parcial do intestino delgado, sinalizando uma melhora na qualidade da recuperação e ausência de grandes complicações ou efeitos colaterais durante o período de hospitalização dos animais estudados.

TERMO DE INDEXAÇÃO: Nutrição parenteral precoce, cães enterectomizados, terapia intensiva, caninos, cirurgia.

\section{INTRODUCTION}

Nutritional support of a critically ill patient is an essential part of supportive care (Remillard 2000). Dogs undergoing the removal of large segments of the small bowel commonly have pre- and postoperative impairment of digestion and absorption. Additionally, vomiting, diarrhea and anorexia contribute to the animals' poor nutritional status. In specific cases, some dogs may develop short bowel syndrome (Davenport et al. 2010).

The resting energy requirement (RER) is provided using the equation $70 \mathrm{x}$ (body weight $[\mathrm{kg}])^{0.75}$, and previous studies have suggested that there is no difference in energy requirements between resting healthy and critically ill dogs (Walton et al. 1996, O'Toole et al. 2004) but that there is a different energy mobilization and use of carbohydrates and lipids. (Pibot et al. 2008). Nevertheless, the final ideal energy requirement is largely undefined (Preiser et al. 2015). A critically ill patient might have different protein requirements due to muscle proteolysis, which can lead to muscle cachexia under the effects of cytokine production, hormonal release, immunosuppression and hemodynamic instability (Wray et al. 2002).

Parenteral nutrition (PN) is a well-established method of administering calories and nutrients to dogs that cannot tolerate traditional enteral feeding routes (Chan 2011). Parenteral nutrition may be delivered into a central vein or a peripheral vein (Remillard \& Saker 2010). Metabolic complications (hyperglycemia, lipemia and hyperbilirubinemia) as well as mechanical and septic complications have been associated with parenteral nutrition (Chan et al. 2002, Queau et al. 2011). However, mechanical and septic complications were not associated with a higher mortality rate. The most common indication for parenteral nutrition is pancreatic disease (Queau et al. 2011).

The parenteral nutrition route is often discussed for nutritional support in case of gastrointestinal tract intolerance; however, the timing for starting therapy is still debatable in dogs (Liu et al. 2012). Early nutritional support is provided until 24 hours after surgery, and recent studies have shown a shorter hospitalization time in animals that received early enteral or parenteral nutritional support compared to late support (Liu et al. 2012).

Lipid emulsions are often used as caloric supplements to critically ill dogs because they increase calorie intake with a lower risk of thrombophlebitis and may be a beneficial calorie supplementation to animals with higher peripheral insulin resistance (Remillard 2000). However, the potential benefit of lipid emulsions in early parenteral nutrition remains unclear.

This study aimed to address the effects of early nutritional parenteral support, with or without lipids, in enterectomized dogs, according to the following parameters: albumin, body weight, recovery score, hospitalization time and laboratory values (complete blood count - CBC and serum chemistry).

\section{MATERIALS AND METHODS}

The Bioethical Commission of this faculty approved this study, and client consent was obtained before the admittance of any dog into the study. Over the course of 1.5 years, 42 dogs were evaluated after enterectomy surgery. The eligibility criteria were as follows: at least three days of anorexia, at least 3 days of daily vomiting and diarrhea episodes, body score of 1-3 (Laflamme 1997) (range 1-9), hypoalbuminemia $(<2.3 \mathrm{mg} / \mathrm{dL})$ and hypokalemia $(<3.8 \mathrm{mEq} / \mathrm{L})$ and a minimum hospitalization time of 24 hours for parenteral nutritional support.

Additionally, before entering the study, all dogs were classified as 3 or 4 points on a 5 -point physical status score (PSS), as follows: $1=$ normal patient with no organic disease; 2 = patient with mild systemic disease; 3 = patient with severe systemic disease limiting activity but not incapacitating; $4=$ patient with incapacitating systemic disease that is a constant threat to life; $5=$ moribund patient not expected to live 24 hours with or without intervention (Brodbelt et al. 2015). Only 18 of the 42 dogs met all of these criteria and were included in the study.

Prior to starting the study, all dogs received potassium supplementation, fluid replacement (Lactated Ringer's solution) by dehydration degree evaluation (DiBartola \& Bateman 2011) and glucose administration if glycemia was less than $60 \mathrm{mg} / \mathrm{dL}$ (reference range: $60-120 \mathrm{mg} / \mathrm{dL}$ ). A serum chemistry panel (urea, creatinine, alkaline phosphatase - AP and alanine aminotransferase - ALT) and $\mathrm{CBC}$ results were obtained prior to surgery and at the end of the study. Total and direct serum bilirubin was measured when serum was icteric. At the end of the surgery, a central polyurethane catheter (I Cath, Becton Dickinson, São Paulo, Brazil) was introduced in the jugular vein. All dogs were randomly assigned into one of the three groups: crystalloid solution (CS), glucose and amino acid (GA) or glucose, amino acid and lipids (GAL).

The CS group received Lactated Ringer's solution according to the following maintenance fluid requirements: the body weight was multiplied by 40 for adult dogs, by 50 for young or large-sized dogs and by 60 for young dogs or dogs weighing $<5 \mathrm{~kg}$ (DiBartola \& Bateman 2011). Animals in the CS group received a 3\% glucose solution and potassium at a rate of $0.3 \mathrm{mEq} / \mathrm{kg} / \mathrm{hour}$. The serum glucose levels were maintained between 60 and $110 \mathrm{mg} / \mathrm{dL}$. The GA and GAL groups did not require glucose or insulin supplementation for blood glucose maintenance. The GA group received central parenteral nutritional (CPN) support with a mixed solution of glucose and amino acids. The GAL group received an individualized CPN support with a mixture of glucose, amino acids and lipids. Individualized solutions were prepared according to weight (Table 1), with components calculated as described in Appendix 1 (Mathews 1996) (Fórmula Medicinal, São Paulo, Brazil). Triglycerides and cholesterol were measured in the GAL group both after surgery and during the hospitalization 
Table 1. Laboratory values, body weight, hospitalization days and number of deceased animals of the CS, GA and GAL groups before surgery and at the end of hospitalization (median, first quarter and third quarter)

\begin{tabular}{|c|c|c|c|c|c|c|c|c|c|}
\hline \multirow{2}{*}{ Variables } & \multirow{2}{*}{ Groups } & \multicolumn{3}{|c|}{ Preoperative } & \multicolumn{3}{|c|}{ End of hospitalization } & \multirow{2}{*}{$\mathrm{p}$-value } & \multirow{2}{*}{$\begin{array}{l}\text { Reference } \\
\text { range }\end{array}$} \\
\hline & & Median & Q1 & Q2 & Median & Q1 & Q2 & & \\
\hline \multirow[t]{3}{*}{ Age (years) } & $\mathrm{CS}$ & 1.00 & 0.67 & 1.50 & 1.00 & 0.67 & 1.50 & & \\
\hline & GAL & 4.50 & 1.50 & 6.00 & 4.50 & 1.50 & 6.00 & & \\
\hline & GA & 3.00 & 2.00 & 4.00 & 3.00 & 2.00 & 4.00 & & \\
\hline \multirow{3}{*}{$\begin{array}{l}\text { Leukocytes } \\
\text { (/mm3) }\end{array}$} & $\mathrm{CS}$ & 19300 & 14500 & 22600 & 12900 & 10050 & 15550 & 0.046 & 6.000 to \\
\hline & GAL & 26750 & 11200 & 35550 & 15050 & 10350 & 30925 & $>0.99$ & 15.000 \\
\hline & GA & 15200 & 14000 & 43300 & 20200 & 18600 & 23600 & 0.69 & \\
\hline \multirow{3}{*}{$\begin{array}{c}\text { Lymphocytes } \\
\text { (/mm3) }\end{array}$} & $\mathrm{CS}$ & 1645 & 954 & 2044 & 1710 & 968 & 4175 & 0.25 & 1.500 to \\
\hline & GAL & 1560 & 1424 & 3620 & 3001 & 2034 & 3705 & 0.89 & 5.000 \\
\hline & GA & 456 & 435 & 840 & 1204 & 1180 & 1600 & 0.5 & \\
\hline \multirow{3}{*}{$\begin{array}{l}\text { Hemoglobin } \\
\text { (g/dL) }\end{array}$} & CS & 11.20 & 9.45 & 12.15 & 11.80 & 7.85 & 13.35 & 0.92 & 12 to 18 \\
\hline & GAL & 10.50 & 7.55 & 13.15 & 10.55 & 8.25 & 12.78 & 0.89 & \\
\hline & GA & 13.00 & 12.90 & 13.50 & 10.10 & 9.00 & 11.20 & 0.08 & \\
\hline \multirow[t]{3}{*}{ BUN (mg/dL) } & $\mathrm{CS}$ & 27.70 & 19.80 & 34.00 & 18.00 & 14.00 & 19.00 & 0.07 & Max 40 \\
\hline & GAL & 23.50 & 12.78 & 38.73 & 21.25 & 14.18 & 21.80 & 0.22 & \\
\hline & GA & 14.00 & 14.00 & 31.80 & 13.00 & 11.60 & 14.00 & 0.89 & \\
\hline \multirow[t]{3}{*}{ Creatinine (mg/dL) } & $\mathrm{CS}$ & 0.76 & 0.62 & 0.82 & 0.80 & 0.62 & 0.97 & 0.92 & 1.5 to 2 \\
\hline & GAL & 1.02 & 0.78 & 1.35 & 1.12 & 0.93 & 1.30 & 0.02 & \\
\hline & GA & 0.96 & 0.88 & 1.20 & 0.93 & 0.70 & 1.00 & 0.34 & \\
\hline \multirow[t]{3}{*}{ ALT (U/L) } & $\mathrm{CS}$ & 32.00 & 14.50 & 45.00 & 51.00 & 29.50 & 79.00 & 0.046 & Max 50 \\
\hline & GAL & 44.00 & 29.50 & 57.00 & 41.00 & 30.75 & 55.45 & 0.67 & \\
\hline & GA & 34.00 & 29.00 & 94.00 & 56.00 & 37.00 & 158.00 & 0.5 & \\
\hline \multirow[t]{3}{*}{$\mathrm{AP}(\mathrm{U} / \mathrm{L})$} & CS & 199.00 & 74.50 & 350.50 & 199.00 & 108.50 & 450.50 & 0.046 & Max 150 \\
\hline & GAL & 163.90 & 140.00 & 189.38 & 213.00 & 174.00 & 222.00 & 0.08 & \\
\hline & GA & 292.70 & 131.00 & 425.00 & 131.00 & 105.00 & 342.00 & 0.893 & \\
\hline \multirow{3}{*}{$\begin{array}{l}\text { Potassium } \\
\text { (mEq/L) }\end{array}$} & $\mathrm{CS}$ & 3.50 & 2.65 & 3.65 & 3.90 & 3.80 & 4.40 & 0.043 & $3.8-5.2$ \\
\hline & GAL & 3.40 & 3.08 & 3.58 & 4.10 & 4.03 & 4.40 & 0.043 & \\
\hline & GA & 3.50 & 3.50 & 3.80 & 4.30 & 4.10 & 4.70 & 0.043 & \\
\hline \multirow[t]{3}{*}{ Albumin (g/dL) } & $\mathrm{CS}$ & 1.60 & 1.30 & 2.10 & 1.50 & 1.15 & 1.80 & 0.59 & $2.5-4.5$ \\
\hline & GAL & 1.40 & 1.33 & 1.55 & 1.75 & 1.70 & 1.88 & 0.038 & \\
\hline & GA & 1.60 & 1.10 & 1.80 & 2.10 & 1.90 & 2.30 & 0.042 & \\
\hline Triglyceride (mg/dl) & GAL & 83.3 & 66.7 & 97.3 & 115 & 104 & 126 & 0.043 & $100-300$ \\
\hline Cholesterol (mg/dl) & GAL & 105 & 82.5 & 134.3 & 134.5 & 107 & 153.5 & 0.043 & $50-100$ \\
\hline \multirow{3}{*}{$\begin{array}{l}\text { Hospitalization } \\
\text { days }\end{array}$} & $\mathrm{CS}$ & 0 & 0 & 0 & 4 & 3 & 4 & & \\
\hline & GAL & 0 & 0 & 0 & 3 & 3 & 3 & & \\
\hline & GA & 0 & 0 & 0 & 3 & 3 & 4 & & \\
\hline \multirow[t]{3}{*}{ Decease animals } & CS & 0.0 & 0.0 & 0.0 & 0.0 & 0.0 & 0.5 & & \\
\hline & GAL & 0.0 & 0.0 & 0.0 & 0.0 & 0.0 & 0.0 & & \\
\hline & GA & 0.0 & 0.0 & 0.0 & 0.0 & 0.0 & 0.0 & & \\
\hline \multirow{3}{*}{$\begin{array}{l}\text { Body weight } \\
\text { (kg) }\end{array}$} & $\mathrm{CS}$ & 8.10 & 4.30 & 18.65 & 7.80 & 4.15 & 17.20 & 0.042 & \\
\hline & GAL & 17.75 & 8.60 & 28.25 & 17.75 & 8.60 & 28.25 & 0.32 & \\
\hline & GA & 6.40 & 4.80 & 7.80 & 6.40 & 4.80 & 7.80 & 0.32 & \\
\hline \multirow[t]{3}{*}{ Body weight (\%) } & $\mathrm{CS}$ & 100 & 100 & 100 & 96 & 95 & 99 & 0.042 & \\
\hline & GAL & 100 & 100 & 100 & 100 & 100 & 100 & 0.32 & \\
\hline & GA & 100 & 100 & 100 & 100 & 100 & 100 & 0.32 & \\
\hline
\end{tabular}

$\overline{\mathrm{BUN}}=$ Blood urea nitrogen, ALT $=$ alanine aminotransferase, $\mathrm{AP}=$ alkaline phosphatase.

period for a lipid infusion assessment. All groups received crystalloid solution for fluid loss replacement when necessary, according to the evolution of hydration degree, urinary output (1 to $2 \mathrm{mg} / \mathrm{kg} /$ hour) and mean arterial blood pressure (minimum of 60mmHg) (DiBartola \& Bateman 2011).

During hospitalization, the heart rate and rhythm, respiratory rate, rectal temperature, arterial blood pressure and urinary output were monitored continuously and recorded 4 times daily. Blood glucose was measured every 6 hours. All dogs were treated, if necessary, with vasoactive (dopamine) (Dopacris ${ }^{\circledR}$, Cristália Ltda, São Paulo, Brazil), synthetic colloid and hemocomponents (Packed red blood cells, hematology laboratory of Veterinary Hospital from São Paulo University). The quality of recovery, based on the animal's responsiveness during hospitalization, 
was assessed daily during the first three days according to the following scores: (1) Active = animal was responsive, barking, moaning, wagging its tail, and able to stand and change body position inside the cage, (2) Responsive = animal remained in lateral recumbency but responded to painful stimulation and handling, and (3) Prostrated = animal remained in lateral recumbency and did not react to painful stimulation or handling but was conscious (Appendix 2). The hospitalization time was defined as the number of days between the surgery and hospital discharge.

The CPN solutions were formulated according to individualized prescriptions and established proportions in the study. The solutions were delivered by an infusion pump (Infusomatcompact ${ }^{\circledR}, \mathrm{B}$. Braun, São Gonçalo, Brazil). The CPN was calculated according to the resting energy requirement for domestic dogs and was based on the following equation: RER $=70 x$ body weight (kilograms) $)^{0.75}$ kcal/day. The CPN was initiated immediately after recovery from anesthesia (Kleiber 1932).

The CPN consisted of $65 \%$ of the RER to avoid excessive feeding and metabolic disorders due to long fasting, and the components are listed in Table 1.

An oral diet was delivered to all groups along with CPN or crystalloid solution based on animal acceptance, in the following order: water was supplied within 12 and 24 hours after the surgery, a liquid diet $(20 \mathrm{ml}$ of water mixed with $170 \mathrm{~g}$ of baby food using a blender) was provided within 24 and 48 hours, and a pureed commercial diet (baby food, beef and vegetables) (Second-stage Nestlé Infant Formula ${ }^{\circledR}$, Nestlé, São José do Rio Pardo, Brazil) was introduced ad libitum within 48 and 72 hours if no vomiting and nausea episodes were observed (Radlinsky 2012). Overall, the dogs received $65 \mathrm{ml} / \mathrm{kg} /$ day of liquid diet, with $0.75 \mathrm{kcal}$ per $\mathrm{ml}$, plus $170 \mathrm{~g}$ of baby food, for a total of $150 \mathrm{kcal}$. Dogs were discharged from the hospital after a 24-hour period of baby food diet ingestion if voluntary intake was observed and no repeated vomiting or severe diarrhea were present.

A software package (SPSS 9.0, IBM, São Paulo, Brazil) using nonparametric tests was used to analyze the data: ANOVA followed by the Wilcoxon test for comparisons along time points (preoperative period and at discharge) within a group and the Kruskal-Wallis test for comparisons between the three experimental groups. The scores for quality of recovery were evaluated within a group using the Friedman test. The significance level for the statistical analysis was considered to be $5 \%(p<0.05)$.

\section{RESULTS}

Eighteen client-owned dogs (10 males and 8 females) of different breeds (4 Miniature Poodles, 3 Cockers Spaniels, 2 Labrador Retrievers, 2 mixed breeds, 1 Boxer, 1 Pitbull, 1 Doberman Pinscher, 1 Great Dane, 1 German Shepherd, 1 Bichon Frisé and 1 Dachshund) and variable ages (range 5 months to 13 years; median 2 years) undergoing small bowel partial resection due to intussusception ( 7 animals), a foreign intestinal body (7 animals), linear foreign intestinal body ( 3 animals), and intussusception associated with a foreign intestinal body (1 animal) were included in this study.

The blood test results, age, body weight, hospitalization time, additional support and number of deceased dogs are summarized in Table 1.

Albumin increased in the GA and GAL groups ( $p=0.042$ and $p=0.038$, respectively) after hospitalization, but no significant difference was identified among the groups. There was an increase in ALT $(p=0.046)$ and AP $(p=0.046)$ in the CS group, serum potassium increased in all groups $(p=0.043)$, and triglycerides and cholesterol increased in the GAL group $(p=0.043)$. Increased bilirubin values were observed in 2 dogs preoperatively ( 1 from the CS group and 1 from the GA group) and in 4 dogs at the end of hospitalization (2 dogs from the CS group and 2 dogs from the GAL group).

Additionally, leukocytes decreased from the first blood panel ( $p=0.046$ ) in the CS group, but no changes were detected in the GAL group; the GA group showed a slight increase in these values, but with no statistical relevance. Four individuals required hemocomponent transfusion ( 3 in CS and 2 in the GAL group) due to blood loss during the surgical procedure and increased clotting time (at least twice the reference values).

Body weight decreased by $4.9 \%(p=0.042)$ in the CS group, but there were no significant changes in the GAL and GA groups ( $p=0.32$ and $p=0.32$ respectively). The recovery scores are summarized in Table 2. The GA and GAL groups showed a significant improvement in general conditions $(p=0.039$ in both groups).

No significant differences in the number of days for oral diet intake or hospitalization time were observed among the groups. Gradual oral diet introduction was accomplished after $3.2 \pm 1.1$ days in the CS group, $2.3 \pm 0.67$ days in the GA group and $2.2 \pm 0.45$ days in the GAL group. The number of days that the animals received PN (hospitalization time) was $4.0 \pm 0.71$ days in the CS group, $3.3 \pm 0.67$ days in the GA group and $3.2 \pm 0.45$ days in the GAL group. The glucose infusion did not lead to complications such as hyperglycemia, and no local infections due to catheter placement were observed in any group during hospitalization. No refeeding syndrome symptoms were detected.

Four dogs died ( 2 from the CS group, 1 from the GA group and 1 from the GAL group) during hospitalization, with severe

Table 2. Number of dogs with scores of quality of recovery (1, 2 and 3) from the CS, GA and GAL groups at the first, second and third days of hospitalization

\begin{tabular}{cccccc}
\hline Groups & Score & Day 1 & Day 2 & Day 3 & p value \\
\hline CS & 1 & 1 & 1 & 2 & 0.15 \\
& 2 & 0 & 2 & 2 & \\
GAL & 3 & 6 & 3 & 2 & \\
& Deceased & 0 & 1 & 0 & \\
& 1 & 1 & 4 & 4 & 0.039 \\
& 2 & 1 & 0 & 1 & \\
GA & 3 & 4 & 1 & 0 & \\
& Deceased & 0 & 1 & 0 & \\
& 1 & 0 & 3 & 2 & 0.039 \\
& 2 & 3 & 2 & 1 & \\
& 3 & 2 & 0 & 1 & \\
& Deceased & 0 & 0 & 1 & \\
\hline
\end{tabular}

Scores of quality of recovery: (1) Active = dog was responsive, barking, moaning, wagging its tail, and able to stand and change body position inside the cage, (2) Responsive = dog remained in lateral recumbency but responded to painful stimulation and handling, and (3) Prostrated $=$ dog remained in lateral recumbency and did not react to painful stimulation or handling but was conscious. 
leukopenia $\left(<2000 / \mathrm{mm}^{3}\right) 24$ hours after the CPN or crystalloid infusion began. No animals were euthanized.

\section{DISCUSSION}

Body weight was maintained in the GA and GAL groups, unlike in the CS group. The prevention of weight loss is an important therapeutic goal in hospitalized animals (Brunetto et al. 2010) and results in early hospital discharge (Liu et al. 2012). The provision of amino acids and glucose improved nitrogen balance, which may be related to the weight maintenance observed in our study.

Another important finding was the improved recovery scores in the GA and GAL groups; this demonstrated that there was a subjective improvement in behavioral responsiveness to clinical staff when GA or GAL were given compared to the CS group, in which the dogs exhibited more apathetic behavior. Furthermore, the overall quality of recovery was better for animals that received parenteral nutrition support.

No validated hospitalization scores were found in the literature review that could be used to evaluate the quality of recovery for dogs. We therefore designed a score for this study because the authors believe that improved animal responsiveness is an important sign of general recovery and an essential element of hospitalization assessment.

Early parenteral nutrition provided within the first 24 hours after surgery is related to a short hospitalization time (Liu et al. 2012) and may play an important role in the clinical course of recovery in critically ill animals. In this study, early nutritional support played an important role in the outcome of the GAL and GA groups compared with the CS group. Although there have been previous publications about early parenteral nutritional complications in humans (Casaer et al. 2011), no complications or side effects such as metabolic and mechanical alterations, hyperkalemia, hyperglycemia and sepsis were seen or were related to parenteral nutrition in the present study.

Additionally, there is a large volume of published studies describing the role of opioids in reducing or exacerbating gastrointestinal dysfunction and hindering the acceptance of oral or enteral feeding (Olan \& Prittie 2015); therefore, early parenteral nutrition may be beneficial in these dogs.

Overall, the GA and GAL groups had better outcomes in terms of nutritional status, including a recovery in albumin values, in contrast to the CS group. Although hypoalbuminemia is a poor reference for malnutrition status (Doweiko \& Nompleggi 1991, Devoto et al. 2006), it possesses an important prognostic value: low albumin values can predict a higher mortality rate in humans (Reinhardt et al. 1980). Trow et al. (2008) detected a higher survival rate in dogs with superior albumin values in animals that received synthetic human albumin. However, albumin cannot be the only predictive factor for hospital recovery because others factors, such as the type and location of surgery, are essential for prognosis (Kudsk et al. 2003).

The percentage of RER was appropriate to maintain body weight in the GA and GAL groups, and the amount provided appeared to be adequate for short-term support. The 65\% RER instead of $100 \%$ was chosen because an enteral diet was gradually provided (Chan \& Freeman 2011) and, following Brunetto et al. (2010), the main goal was weight maintenance, and not weight gain to previous body condition, prior to the current illness.
The inclusion of a lipid emulsion in the CPN resulted in no significant improvement compared to the non-lipid solutions, which may be attributed to the short period of CPN infusion in the studied dogs (Chan \& Freeman 2011, Queau et al. 2011). However, in some cases, such as peripheral insulin resistance (Liu et al. 2012) or in an attempt to decrease the PN solution osmolarity to allow delivery through a peripheral vessel, a lipid emulsion may be essential (Remillard \& Saker 2010).

This is an important point to consider because the inclusion of lipids increases the price of solutions and may be associated with hyperbilirubinemia in septic animals (Chandler \& Payne-James 2006). In agreement with our results, a recent study using parenteral nutrition without lipid emulsion showed a positive result in providing sufficient calories to critically ill dogs (Gajanayake et al. 2013).

As expected, serum triglycerides and cholesterol were increased in the GAL group (Table 1), but gross serum lipemia was not recognized in any dog. This contrasts with earlier findings, in which lipemia was reported in $24 \%$ of the subjects; however, the main disease involved in other studies was pancreatitis, which was not selected in this study (Queau et al. 2011). Triglycerides and cholesterol were measured only in the GAL group to assess the CPN. The other two groups were not tested for these parameters because they were not receiving exogenous lipids.

Four dogs died during hospitalization with severe leukopenia. It seems possible that their death was associated to severe pre-operatory systemic infection, and not correlated to the administered parenteral nutrition.

There are several limitations in this study to be considered, including the small number of dogs, which may have prevented the detection of any significant effects caused by other variables. This was a clinical study involving critically ill patients, and the inclusion of animals was limited due to strict selection criteria and available time to enroll subjects. In addition, dogs that died within the first 24 hours after surgery were excluded, thus decreasing the final number of dogs.

Calorie intake was not precisely quantified for the enteral diet. At the moment of discharge, it was not possible to assess if the calorie intake was adequate for every dog and whether the hospitalization period would be affected by this factor as shown in Brunetto et al. (2010).

Additionally, an APPLE score (Acute Patient Physiologic and Laboratory Evaluation) would provide a relevant assessment of prognosis for each dog, and a better patient standardization that considered illness severity was not performed because insufficient laboratorial evaluations were available (Hayes et al. 2010). Furthermore, triglycerides and cholesterol were not evaluated in all groups. However, hypertriglyceridemia might be present in malnourished dogs, which would be an important element to analyze in all groups, regardless of lipid infusion.

The results of this study suggest that early parenteral nutrition may play an important role in recovery time in dogs that underwent partial resection of their small intestine and it is non-harmful. CPN provided weight maintenance and improved recovery scores and no relevant metabolic or mechanical complications were detected in the enterectomized dogs. Additionally, the inclusion of lipids in the short-term CPN did not benefit this population of dogs. 
Acknowledgements.- Supported by a grant from Sao Paulo Research Foundation (FAPESP 2004/11823-9).

\section{REFERENCES}

Brodbelt D.C., Flaherty D. \& Pettifer G.R. 2015. Anesthetic risk and informed consent, p.11-22. In: Grimm K.A., Lamont L.A., Tranquilli W.J., Greene S.A. \& Robertson S.A. (Eds), Veterinary Anesthesia and Analgesia. 5th ed. Wiley-Blackwell, Iowa.

Brunetto M.A., Gomes M.O.S., Andre M.R., Teshima E., Gonçalves K.N.V., Pereira G.T., Ferraudo A.S. \& Carciofi A.C. 2010. Effects of nutritional support on hospital outcome in dogs and cats. J. Vet. Emerg. Crit. Care, San Antonio, 20(2):224-231. http://dx.doi.org/10.1111/j.1476-4431.2009.00507.x. PMid:20487250.

Casaer M.P., Mesotten D., Hermans G., Wouters P.J., Schetz M., Meyfroidt G., Van Cromphaut S., Ingels C., Meersseman P., Muller J., Vlasselaers D., Debaveye Y., Desmet L., Dubois J., Van Assche A., Vanderheyden S., Wilmer A. \& Van den Berghe G. 2011. Early versus late parenteral nutrition in critically ill adults. N. Engl. J. Med. 365(6):506-517. http://dx.doi.org/10.1056/ NEJMoa1102662. PMid:21714640.

Chan D.L. \& Freeman L.M. 2011. Parenteral nutrition, p.584-601. In: DiBartola S.P. (Ed.), Fluid, Electrolyte, and Acid-Base Disorders in Small Animal Practice: fluid therapy in small animal practice. 4th ed. Saunders Elsevier, Philadelphia.

Chan D.L. 2011. Parental nutritional support, p.1857-1872. In: Ettinger S.J. \& Feldman E.C. (Eds), Textbook of Veterinary Internal Medicine. 7 th ed. Saunders Elsevier, St Louis.

Chan D.L., Freeman L.M., Labato M.A. \& Rush J.E. 2002. Retrospective evaluation of partial parenteral nutrition in dogs and cats. J. Vet. Intern. Med. 16(4):440-445. http://dx.doi.org/10.1111/j.1939-1676.2002. tb01262.x. PMid:12141306.

Chandler M.L. \& Payne-James J.J. 2006. Prospective evaluation of a peripherally administered three-in-one parenteral nutrition product in dogs. J. Small Anim. Pract. 47(9):518-523. http://dx.doi.org/10.1111/j.17485827.2006.00173.x. PMid:16961469.

Davenport D.J., Ludlow C.L. \& Remillard R.L. 2010. Short bowel syndrome, p.1085-1092. In: Hand M.S., Thatcher C.D., Remillard R.L., Roudebush P. \& Novotny B.J. (Eds), Small Animal Clinical Nutrition. 5th ed. Mark Morris Institute, Topeka.

Devoto G., Gallo F., Marchello C., Racchi O., Garbarini R., Bonassi S., Albalustri G. \& Haupt E. 2006. Prealbumin serum concentrations as a useful tool in the assessment of malnutrition in hospitalized patients. Clin. Chem. 52(12):2281-2285. http://dx.doi.org/10.1373/clinchem.2006.080366. PMid:17068165.

DiBartola S.P. \& Bateman S. 2011. Introduction to fluid therapy, p.331-350. In: DiBartola S.P. (Ed.), Fluid, Electrolyte, and Acid-Base Disorders in Small Animal Practice: fluid therapy in small animal practice. 4th ed. Saunders Elsevier, Philadelphia.

Doweiko J.P. \& Nompleggi D. 1991. The role of albumin in human physiology and pathophysiology, Part III: Albumin and disease states. JPEN J. Parenter. Enteral. Nutr. 15(4):476-483. http://dx.doi.org/10.1177/01486071910 15004476. PMid:1895489.

Gajanayake I., Wylie C.E. \& Chan D.L. 2013. Clinical experience with a lipidfree, ready-made parenteral nutrition solution in dogs: 70 cases (20062012). J. Vet. Emerg. Crit. Care, San Antonio, 23(3):305-313. http://dx.doi. org/10.1111/vec.12029. PMid:23461694.

Hayes G., Mathews K., Doig G., Kruth S., Boston S., Nykamp S., Poljak Z. \& Dewey C. 2010. The acute patient physiologic and laboratory evaluation (APPLE) score: a severity of illness stratification system for hospitalized dogs. J. Vet. Intern. Med. 24(5):1034-1047. http://dx.doi.org/10.1111/j.19391676.2010.0552.x. PMid:20629945.
Kleiber M. 1932. Body size and metabolism. Hilgardia 6(11):315-351. http:// dx.doi.org/10.3733/hilg.v06n11p315.

Kudsk K.A., Tolley E.A., DeWitt R.C., Janu P.G., Blackwell A.P., Yeary S. \& King B.K. 2003. Preoperative albumin and surgical site identify surgical risk for major postoperative complications. JPEN J. Parenter. Enteral. Nutr. 27(1):19. http://dx.doi.org/10.1177/014860710302700101. PMid:12549591.

Laflamme D. 1997. Development and validation of a body condition score system for dogs. Canine Pract. 22:10-15.

Liu D.T., Brown D.C. \& Silverstein D.C. 2012. Early nutritional support is associated with decreased length of hospitalization in dogs with septic peritonitis: A retrospective study of 45 cases (2000-2009). J. Vet. Emerg. Crit. Care, San Antonio, 22(4):453-459. http://dx.doi.org/10.1111/j.14764431.2012.00771.x. PMid:22928749.

Mathews K.A. 1996. Nutricional support: parenteral nutrition, p.20-29. In: Mathews K.A. (Ed.), Veterinary Emergency and Critical Care Manual. Lifelearn, Guelph.

O’Toole E., Miller C.W., Wilson B.A., Mathews K.A., Davis C. \& Sears W. 2004. Comparison of the standard predictive equation for calculation of resting energy expenditure with indirect calorimetry in hospitalized and healthy dogs. J. Am. Vet. Med. Assoc. 225(1):58-64. http://dx.doi.org/10.2460/ javma.2004.225.58. PMid:15239474.

Olan N.V. \& Prittie J. 2015. Retrospective evaluation of ProcalAmine administration in a population of hospitalized ICU dogs: 36 cases (20102013). J. Vet. Emerg. Crit. Care, San Antonio, 25(3):405-412. http://dx.doi. org/10.1111/vec.12306. PMid:25900575.

Pibot P., Biourge V. \& Elliott D. 2008. Encyclopedia of Canine Clinical Nutrition Aniwa SAS, Aimargues, France.

Preiser J.C., van Zanten A.R., Berger M.M., Biolo G., Casaer M.P., Doig G.S. Griffiths R.D., Heyland D.K., Hiesmayr M., Iapichino G., Laviano A., Pichard C., Singer P., Van den Berghe G., Wernerman J., Wischmeyer P. \& Vincent J.L. 2015. Metabolic and nutritional support of critically ill patients: consensus and controversies. Crit. Care 19(1):35. PMid:25886997.

Queau Y., Larsen J.A., Kass P.H., Glucksman G.S. \& Fascetti A.J. 2011. Factors associated with adverse outcomes during parenteral nutrition administration in dogs and cats. J. Vet. Intern. Med. 25(3):446-452. http://dx.doi. org/10.1111/j.1939-1676.2011.0714.x. PMid:21457322.

Radlinsky M.G. 2012. Surgery of the digestive system, p.386-584. In: Fossum T.W. (Ed.), Small Animal Surgery. 4th ed. Elsevier Mosby, St Louis.

Reinhardt G.F., Myscofski J., Wilkens D., Dobrin P., Mangan Jr J.J. \& Stannard R. 1980. Incidence and Mortality of Hypoalbuminemic Patients in Hospitalized Veterans. JPEN J. Parenter. Enteral. Nutr. 4(4):357-359. http://dx.doi. org/10.1177/014860718000400404. PMid:6774116.

Remillard R.L. \& Saker K.E. 2010. Parenteral-assisted feeding, p.477-500. In Hand M.S., Thatcher C.D., Remillard R.L., Roudebush P. \& Novotny B.J. (Eds), Small Animal Clinical Nutrition. 5th ed. Mark Morris Institute, Topeka.

Remillard R.L. 2000. Assited feeding in hospitalized patients: enteral and parenteral, p.352-399. In: Hand M.S., Thatcher C.D., Remillard R.L., Roudebush P. \& Lewis L.D. (Eds), Small Animal Clinical Nutrition. 4th ed. Mark Morris Institute, Philadelphia.

Trow A.V., Rozanski E.A., Delaforcade A.M. \& Chan D.L. 2008. Evaluation of use of human albumin in critically ill dogs: 73 cases (2003-2006). J. Am. Vet. Med. Assoc. 233(4):607-612. http://dx.doi.org/10.2460/javma.233.4.607. PMid:18710318.

Walton R.S., Wingfield W.E., Ogilvie G.K., Fettman M.J. \& Matteson V.L. 1996 Energy expenditure in 104 postoperative and traumatically injured dogs with indirect calorimetry. J. Vet. Emerg. Crit. Care 6(2):71-79. http://dx.doi. org/10.1111/j.1476-4431.1996.tb00035.x.

Wray C.J., Mammen J.M. \& Hasselgren P.-0. 2002. Catabolic response to stress and potential benefits of nutrition support. Nutrition 18(11/12):971-977. http://dx.doi.org/10.1016/S0899-9007(02)00985-1. PMid:12431720. 
Appendix 1. Guideline for the CPN calculation for each animal of GA and GAL group

RER $($ Kcal per day $)=(\text { weight }(\mathrm{kg}))^{0.75} \times 70$
$65 \%$ RER =

(final calculated energy)

Glucose: 50\% (GAL group) or 100\% (GA group) of final calculated energy

Lipids: $50 \%$ (GAL group) or $0 \%$ (GA group) of final calculated energy

Amino acid: $6 \mathrm{~g}$ per $100 \mathrm{kcal}$ of final calculated energy

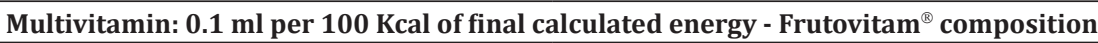

Retinyl palmitate (Vitamin A): $10.000 \mathrm{UI}$

Riboflavin (Vitamin B2): 5 mg

Nicotinamide: $100 \mathrm{mg}$

Dexpanthenol: $25 \mathrm{mg}$

Stabilizing medium qsp: $10 \mathrm{mg}$ (sodium edate, benzalkonium chloride, sodium bicarbonate, polysorbate 80, water for injection)
Cholecalciferol (Vitamin D): 800 UI

Ascorbic acid (Vitamin C):

Pyridoxine (Vitamin B6): $15 \mathrm{mg}$

Tocopheryl acetate (Vitamin E): $50 \mathrm{~ms}$
Chromium: $10 \mathrm{mcg} / \mathrm{ml}$

Copper: $0.8 \mathrm{mg} / \mathrm{ml}$

Final Volume:

mL 50\% Glucose

$\mathrm{mL} 10 \%$ amino acids adult

mL 20\% lipids

__ mL multivitamins

mL water

Electrolytes*

igo elements: $0.1 \mathrm{ml}$ per $100 \mathrm{Kcal}$ of final calculated energy

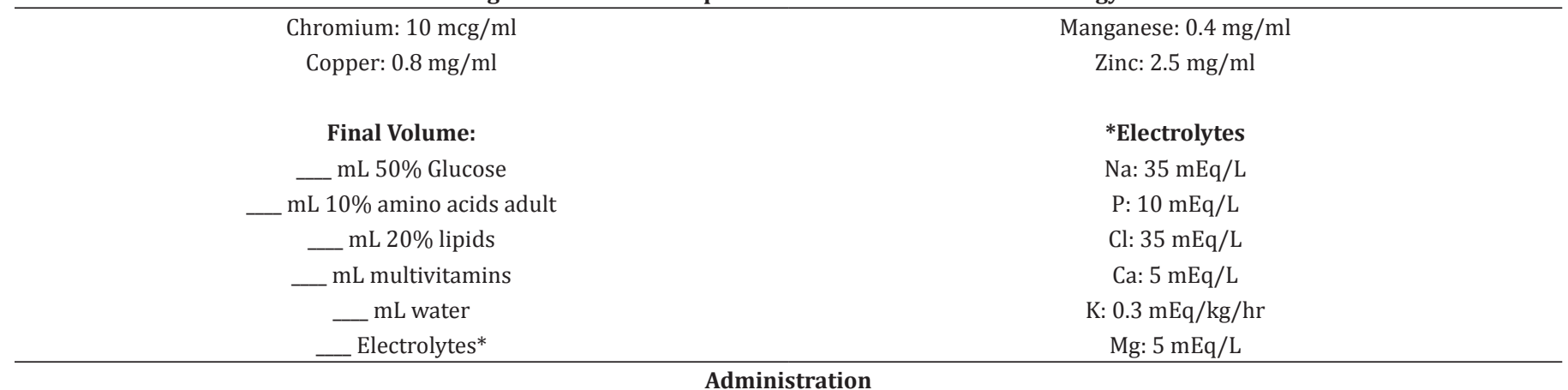

(CPN total volume) $/ 24$ hours $=\mathrm{ml}$ per hour

Weight $\mathrm{x} 70=\mathrm{ml}$ per day

Bidistilled water was added to the final solution to achieve a volume of $70 \mathrm{ml} / \mathrm{kg} /$ day

Maximal osmolality was $750 \mathrm{mOsm} / \mathrm{l}$

Appendix 2. Post-anesthetic recuperation chart

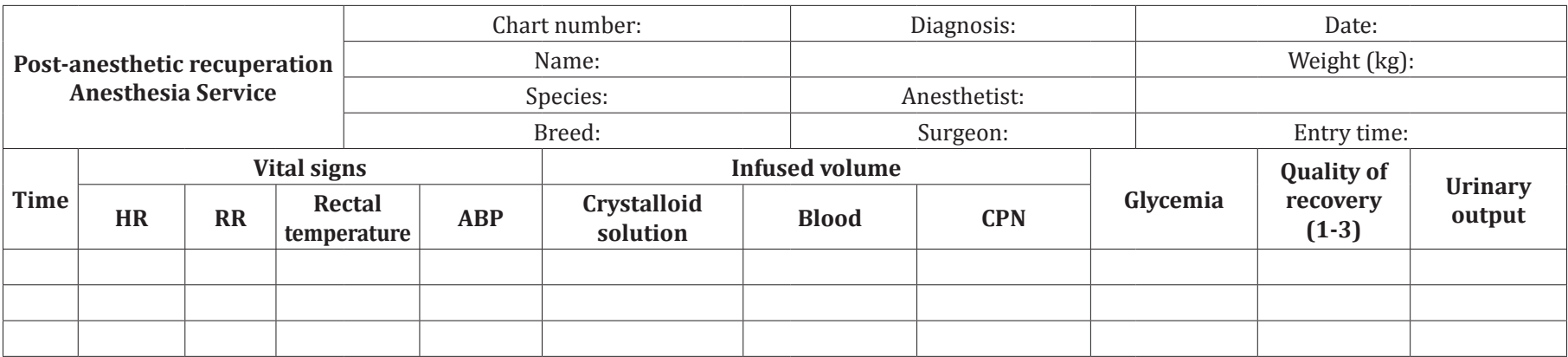

$\mathrm{HR}=$ heart rate, $\mathrm{RR}=$ respiratory rate $\mathrm{ABP}=$ arterial blood pressure. Quality of recovery: (1) Active = dog was responsive, barking, moaning, wagging its tail and able to stand and change body position inside the cage, (2) Responsive: dog remained in lateral recumbency but responded to painful stimulation and handling, (3) Prostrated: dog remained in lateral recumbency and did not react to painful stimulation or handling but was conscious. 